\title{
Outcomes-Based Evaluation of Graduation Requirements for Traffic Engineering Education: An Example of Road Traffic Safety Course *
}

\author{
Jinxing Shen ${ }^{1}$ \\ Hohai University \\ Junjie $\mathrm{Qi}^{4}$ \\ Hohai University
}

\author{
Yanan $\mathrm{Liu}^{2}$ \\ Hohai University
}

\author{
Genghua $\mathrm{Ma}^{3}$ \\ Hohai University
}

Changjiang Zheng
Hohai University

\begin{abstract}
Outcomes-based evaluation of graduation requirements can provide foundations for continuous improvement of professional education, and is the core requirement of the engineering education accreditation. According to the graduation requirements for traffic engineering education, outcomes-based evaluation is carried out in this paper using the exam scores analytical method and rubrics method. Taking road traffic safety course as an example, based on the analysis of the relationship between graduation requirements and curriculum contents, graduation requirement evaluation indicator and weight coefficient of connected curriculum contents are determined. Then, test scores of 169 students, who have taken this course in the past three years, were selected to calculate the achievement of each evaluation indicator point based on exam scores analytical method. Moreover, on the basis of 162 valid questionnaires, the quantitative evaluation data of the graduation requirements for the curriculum contents are calculated. And the rubrics evaluation value, evaluation opinions and the feedback of key teachers are obtained using rubrics method. The research in this paper can provide guidance to better improve the quality of course construction and meet the graduation requirements of engineering education accreditation.
\end{abstract}

\section{Keywords}

Outcomes-Based Evaluation • Engineering Education Accreditation • Graduation Requirements • Road Traffic Safety Curriculum

\footnotetext{
"This work is supported by Research Project on Higher Education Teaching Reform in Jiangsu Province(2017JSJG029), Research Project on the 13th Five-Year Plan for Education Science in Jiangsu Province(C-a/2016/01/25), Jiangsu Planned Projects for Postdoctoral Research Funds (Grant No. 1701086B), Natural Science Foundation of Jiangsu Province (Grant No. BK20170879), and National Natural Science Foundation of China (Grant No. 51808187).

${ }^{1}$ Correspondence to: Jinxing Shen (PhD), College of Civil and Transportation Engineering, Hohai University, Nanjing 210098, China. Email: shenjx03@163.com

${ }^{2}$ College of Civil and Transportation Engineering, Hohai University, Nanjing 210098, China. Email: Lyn_0701@163.com ${ }^{3}$ College of Harbour, Coastal and Offshore Engineering, Hohai University, Nanjing 210098, China. Email: magenghua@hhu.edu.cn

${ }^{4}$ College of Civil and Transportation Engineering, Hohai University, Nanjing 210098, China. Email: qjj.energetic@qq.com ${ }^{5}$ College of Civil and Transportation Engineering, Hohai University, Nanjing 210098, China. Email: zhenghhu@ sina.com
}

Citation: Shen, Liu, Ma, Qi, \& Zheng. (2018). Outcomes-Based Evaluation of Graduation Requirements for Traffic Engineering Education: An Example of Road Traffic Safety Course. Educational Sciences: Theory \& Practice, 18(5), 2254-2265. http://dx.doi.org/10.12738/estp.2018.5.124 
Higher education plays an important role in the further development of sustainability (Thurer, Tomasevic, Stevenson, Qu, \& Huisingh, 2018). Education for sustainable development efforts generally aim to train students understand the world in a more holistic way and anticipate consequences of different actions (Svanstrom, Sjoblom, Segalas, \& Froling, 2018). Traditional higher education, especially engineering education, focuses on response to needs or demands of employers, industry and the marketplace (Staniskis, \& Katiliute, 2016). Currently, engineering education faces great challenge of training a large number of college students to meet the requirements of high-tech industries ( $\mathrm{Li}, 2018)$. Such needs or demands requires a rigorous engineering education to advance the frontiers of knowledge, integrate new technologies from the laboratory to society and finally qualify students as engineers and the society leaders (Chaubey, Bhattacharya, \& Das Mandal, 2018).

Three decades ago, developed countries cultivated the majority engineers of the world. Today, a large proportion of new engineering graduates come from China, India, Brazil and Russia, collectively known as the BRIC countries (Mutereko, 2018). In order to guarantee and improve the quality of engineering education, more and more universities or institutions begin to implement engineering education accreditation. Accreditation has emerged as a symbol of high quality where teaching practices could be externally evaluated against explicit standards (Wikle, 2018). With the help of peer review, engineering education accreditation could improve instructional quality and increase the international appeal of these graduates (Anwar, \& Richards, 2013). In New Zealand, engineering education is subject to general quality assurance requirements as a precondition of government funding. And all of the New Zealand tertiary providers of engineering degrees have chosen to seek and maintain accreditation from the Institution of Professional Engineers New Zealand (Hodgson, \& Williams, 2007). In October 2015, China engineering education accreditation association (CEEAA) was established. This is a national social group composed of institutions and individuals related to engineering education. By organizing and implementing engineering education accreditation, the quality of engineering education will be improved and the international competitiveness of engineering education in China will be enhanced. There are seven international agreements administered by the International Engineering Alliance (IEA). Referred to as international mutual recognition agreements and internationally accepted by quality assurance system for engineering education. Those agreements are also the important basis for achieving international mutual recognition of engineering education. As one of the most important agreements, the Washington Accord was established in 1989, with 20 signatory bodies with full rights and 5 with provisional status (Anwar, \& Richards, 2018). In June 2016, China officially joined the Washington Accord. And engineering graduates accredited by CEEAA will be recognized by other organizations of the Washington Accord.

Outcomes-based education (OBE) is a recent development in modern curriculum planning, which has been adopted in education systems by the signatories of the Washington Accord. (Mukhopadhyay, \& Smith, 2010). It is a performance-based and learner-centered approach in education offering a powerful and appealing way of reforming and managing education (Tan, Chan, Subramaniam, \& Ping, 2018). The philosophy of OBE is to train individuals who can demonstrate the evidence of competencies in designated areas of education (Kim, 2012). The key principle in this education approach is the development of educational programs and application of learning processes with the beginning in identifying outcomes, that is, competencies expected as the results 
Shen, Liu, Ma, Qi, Zheng / Outcomes-Based Evaluation of Graduation Requirements for Traffic Engineering...

of an educational process. By taking into account pre-post differences and controlling for initial performance levels, it facilitates an appraisal of performance gain for specific learning objectives (Schiekirka, Anders, \& Raupach, 2014). Practicing OBE made some teachers reflect upon what constitutes knowledge and competency (Barman, Silen, \& Laksov, 2014). Thus OBE is served as a framework for reflection on teaching-learning of competence within their field and consequently they strived to design their course to facilitate the development of integrated competencies. In Hong Kong, OBE is a current initiative in universities, with widespread backing by governments and standards bodies (Deneen, Brown, Bond, \& Shroff, 2013).

OBE emphasizes on what learners should know and understand how to adapt to future life roles. Estimating learning outcome from comparative student self-ratings is a reliable and valid method to identify specific strengths and shortcomings in undergraduate curricula (Schiekirka, Anders, \& Raupach, 2014). However, studies to evaluate students' perceptions of OBE and validate the understanding of these perceptions are lacking, caution must be taken to ensure that the curriculum is not narrowly centered on the interests of the powerful labor market but responsive to students' and other societal needs (Mutereko, 2018). In addition, there are few evaluation tools directly assess learning outcome for specific learning objectives (Schiekirka, Anders, \& Raupach, 2014). Thus, taking road traffic safety curriculum as an example, this paper expounds the practical process of outcome-based evaluation for the graduation requirements of traffic engineering education. The research can provide guidance to better improve the quality of curriculum construction and meet the graduation requirements of engineering education accreditation. The rest of this paper is organized as follows. Outcomebased evaluation methods are developed in Section 2. Then, based on the proposed methods, graduation requirements of road traffic safety curriculum were evaluated in Section 3. Conclusions are drawn and discussed in Section 4.

\section{Methods}

The core of engineering education certification is to confirm that engineering graduates meet the accreditation of the industry, which is a qualification evaluation oriented to OBE. The approach of outcomesbased evaluation mainly includes direct evaluation method and indirect evaluation method. The direct evaluation methods evaluate the achievement of the graduation requirements indicator of the curriculum by direct observation or inspection effectiveness, mainly including the score analysis method and the ruler evaluation method. Indirect evaluation methods are used to indirectly speculate and evaluate learning effects of students through questionnaire surveys or self-reports. In this paper, the practical process of outcomes-based evaluation for the graduation requirement of traffic engineering education with exam scores analytical method and rubrics method.

\section{Exam scores analytical method}

According to the training plan and the curriculum syllabus, the steering committee for teaching in traffic engineering (SCTE) clarify the relationship between the graduation requirement indicators and the content of all curricula. And based on the requirements of graduation ability, the relationship among them could be evaluated as high, medium and low. The evaluation indicators will be selected when the relationship is assessed 
Shen, Liu, Ma, Qi, Zheng / Outcomes-Based Evaluation of Graduation Requirements for Traffic Engineering...

as high or medium. Then determine the weight coefficient of support of graduation ability requirement by the professional teaching guidance committee.

The fulfillment of graduation requirements is calculated as follows. Firstly, the correspondence between each achievement indicator and the teaching activity of the graduation requirement of the major is established. The teaching activity is determined according to the support intensity of the teaching activity on the graduation requirement achievement indicators. According to the evaluation of the operation and evaluation links, the evaluation links are decomposed, and the evaluation scores are calculated by using the average evaluation scores and total scores of all the graduates evaluated. The calculation method could be expressed by Equation 1. It is the average evaluation score of the corresponding indicator item supported by the teaching activity, and is divided by the full value of the evaluation point supported by the teaching activity.

$$
V_{i}=W_{i} \times A_{i} / T_{i}
$$

Where,

$V_{i}=$ Evaluation value of indicator $i$,

$W_{i}=$ Weight of indicator $i$,

$A_{i}=$ Average evaluation score of indicator $i$,

$T_{i}=$ Total evaluation score of indicator $i$

\section{Rubrics method}

A commonly used definition of rubric is a document that articulates the expectations for an assignment by listing the criteria or what counts, and describing levels of quality from excellent to poor. In general, rubric have three basic characteristics, which is evaluation criteria, quality definition, and scoring strategies. The evaluation criteria are factors that the evaluator considers when determining the quality of the student's work. The standard is also described as a set of indicators or a list of guidelines that reflect processes and content that are considered important. The quality definition provides a detailed explanation of what the student must do to demonstrate skill, proficiency or standards to achieve a particular level of achievement, such as poor, fair or excellent. The quality definition addresses the need to distinguish between good and poor responses, both for scoring purposes and for providing feedback to students. Rubrics' scoring strategy involves using a scale to explain the judgment of a product or process

General procedure of teaching activities based on rubrics method is as follows. Firstly, the basic model of the evaluation rubrics is established. The quantitative evaluation and sample data of the students' graduation requirements for the course support are obtained. An evaluation rubrics table based on the average score of the sample space is generated. Then, according to the sample rubrics table, the members of the teaching steering committee gave evaluation opinions and the lecturer gave feedback based on this and wrote corrective measures.

Taking the course of road traffic safety as an example, according to decomposition indicators of graduation requirements of transportation engineering major, the evaluation indicators of graduation requirements related to road traffic safety course are obtained, as shown in Table 1. 
Table1

Evaluation Indicators of Graduation Requirements Related to Road Traffic Safety Course

\begin{tabular}{ll}
\hline $\begin{array}{l}\text { Evaluation } \\
\text { indicator }\end{array}$ & \multicolumn{1}{c}{ Explanation of the evaluation indicators } \\
\hline $1-4$. & $\begin{array}{l}\text { Ability to apply professional knowledge to solve complex engineering problems such as } \\
\text { traffic engineering planning, design, control, and safety. }\end{array}$ \\
\hline $2-2$ & $\begin{array}{l}\text { Ability to apply the basic principles of mathematics and natural science knowledge to } \\
\text { transform, express and analyze the characteristics of complex transportation system to } \\
\text { obtain effective conclusions. }\end{array}$ \\
\hline $4-2$ & $\begin{array}{l}\text { Ability to apply the scientific principles and scientific methods to analyze and interpret } \\
\text { the data of complex traffic engineering problems and obtain effective conclusions. }\end{array}$ \\
\hline $5-2$ & $\begin{array}{l}\text { Ability to design and simulate complex engineering problems such as traffic engineering } \\
\text { planning, design, and control. }\end{array}$ \\
\hline $10-1$ & $\begin{array}{l}\text { Ability to write high quality analysis reports and effective design plans for complex } \\
\text { traffic engineering problems. }\end{array}$ \\
\hline
\end{tabular}

Based on the evaluation indicators of graduation requirements related to road traffic safety courses, the basic model of the Rubrics method for students is expounded in Table2. The course related to the graduation requirements of the major are shown in the first column of Table2. The content of the third line in the table is the achievement of the indicators, which is divided into three levels. The internal content of the table provides specific explanations for different levels of each indicator.

Table2

Basic Model of the Rubrics Method for Students

\begin{tabular}{|c|c|c|c|c|}
\hline \multirow{2}{*}{$\begin{array}{l}\text { Name } \\
\text { Course } \\
\text { Name } \\
\end{array}$} & & \multicolumn{3}{|l|}{ Student ID } \\
\hline & Road traffic safety & Evaluation time & & \\
\hline $\begin{array}{l}\text { Scoring } \\
\text { criteria } \\
\text { evaluation } \\
\text { indicator }\end{array}$ & $\begin{array}{l}\text { Excellent } \\
(100-85)\end{array}$ & $\begin{array}{c}\text { Medium } \\
(84-70)\end{array}$ & $\begin{array}{l}\text { Failed } \\
(69-0)\end{array}$ & Score \\
\hline $1-4$. & $\begin{array}{l}\text { Graduates can apply } \\
\text { professional knowledge } \\
\text { to solve complex traffic } \\
\text { safety problems. }\end{array}$ & $\begin{array}{l}\text { Graduates can solve } \\
\text { general traffic safety } \\
\text { problems with common } \\
\text { knowledge. }\end{array}$ & $\begin{array}{l}\text { Under the guidance of } \\
\text { professional, graduates } \\
\text { can solve simple traffic } \\
\text { safety problems. }\end{array}$ & \\
\hline $2-2$ & $\begin{array}{l}\text { Graduates can apply } \\
\text { natural science } \\
\text { knowledge to analyze } \\
\text { the complex } \\
\text { characteristics of traffic } \\
\text { safety problems. }\end{array}$ & $\begin{array}{l}\text { Graduates can analyze } \\
\text { characteristics of general } \\
\text { traffic safety problems } \\
\text { with common knowledge. }\end{array}$ & $\begin{array}{l}\text { Under the guidance of } \\
\text { professional, graduates } \\
\text { can analyze } \\
\text { characteristics of simple } \\
\text { traffic safety problems. }\end{array}$ & \\
\hline $4-2$ & $\begin{array}{l}\text { Graduates can analyze } \\
\text { and interpret the data of } \\
\text { complex traffic safety } \\
\text { problems and obtain } \\
\text { effective conclusions. }\end{array}$ & $\begin{array}{l}\text { Graduates can analyze } \\
\text { and interpret the data of } \\
\text { general traffic safety } \\
\text { problems and obtain } \\
\text { correct conclusions. }\end{array}$ & $\begin{array}{l}\text { Under the guidance of } \\
\text { professional, graduates } \\
\text { can analyze the data of } \\
\text { simple traffic safety } \\
\text { problems and obtain } \\
\text { reasonable conclusion. }\end{array}$ & \\
\hline $5-2$ & $\begin{array}{l}\text { Graduates can design } \\
\text { and simulate complex } \\
\text { traffic safety problems. }\end{array}$ & $\begin{array}{l}\text { Graduates can design and } \\
\text { simulate general traffic } \\
\text { safety problems. }\end{array}$ & $\begin{array}{l}\text { Graduates can design or } \\
\text { simulate simple traffic } \\
\text { safety problems. }\end{array}$ & \\
\hline $10-1$ & $\begin{array}{l}\text { Graduates can write } \\
\text { high quality analysis } \\
\text { reports and effective } \\
\text { design plans for } \\
\text { complex traffic safety } \\
\text { problems. }\end{array}$ & $\begin{array}{l}\text { Graduates can write } \\
\text { analysis reports and } \\
\text { design plans for general } \\
\text { traffic safety problems. }\end{array}$ & $\begin{array}{l}\text { Graduates can write } \\
\text { analysis reports for } \\
\text { simple traffic safety } \\
\text { problems. }\end{array}$ & \\
\hline
\end{tabular}


The SCTE has designed and distributed investigation table to some graduates from the course to obtain a quantitative evaluation of the graduation requirements of the course. The SCTE summarizes and obtains the evaluation table based on the sample space average score. Subsequently, according to the evaluation table, the SCTE gives an evaluation opinion on the course. Finally, the lecturer will give feedback based on the evaluation opinions given by the SCTE, and clarify the specific teaching rectification measures.

\section{Research Contents}

\section{Survey Analysis}

The methodology presented in this paper was put into practice in Hohai University (HHU), China. Situated in the old capital city Nanjing, HHU has a one-hundred-year-long history and enjoys high prestige. As a key comprehensive university under the direct supervision of the ministry of education, HHU has upgraded itself with good momentum of development in hydraulic engineering and water resources as its main focus, education of engineering subjects as its first priority, and coordinated development of a wide array of disciplines covering engineering, sciences, economics, management, liberal arts and law, ranking among China's top universities in its teaching indexes and overall strength. Nowadays, HHU offers 54 undergraduate programs. The transportation engineering specialty of Hohai University was listed as the key professional construction of the "Twelfth Five-Year Plan" of Jiangsu Province. It trains senior professionals with relevant professional knowledge and can engage in transportation planning, traffic engineering design, construction and management in various departments of the state, province and city.

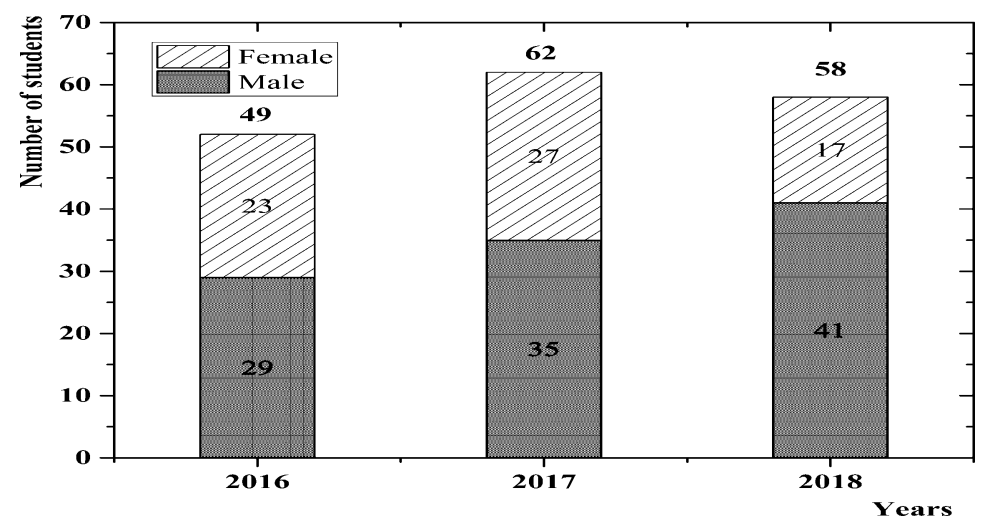

Figure 1. Students of course selection

Road traffic safety is one of the main professional curriculum for undergraduates majoring in transportation engineering. The main task of this course is to enable students to master the basic concepts and basic theories of traffic safety. Students will be educated to use the safety analysis and evaluation of transportation systems and the theory and methods of traffic accident prevention to solve practical problems. The curriculum also provides students with the basic ability to comprehensively analyze and handle various types of traffic safety 
issues. Over the past 3 years, more than 50 students have chosen this course each year. With the serious situation of road traffic safety, more and more students begin to choose this curriculum. In 2017, the number of students choosing this course reached to 62 , and the proportion of male students in the course is increasing, as shown in Figure 1.

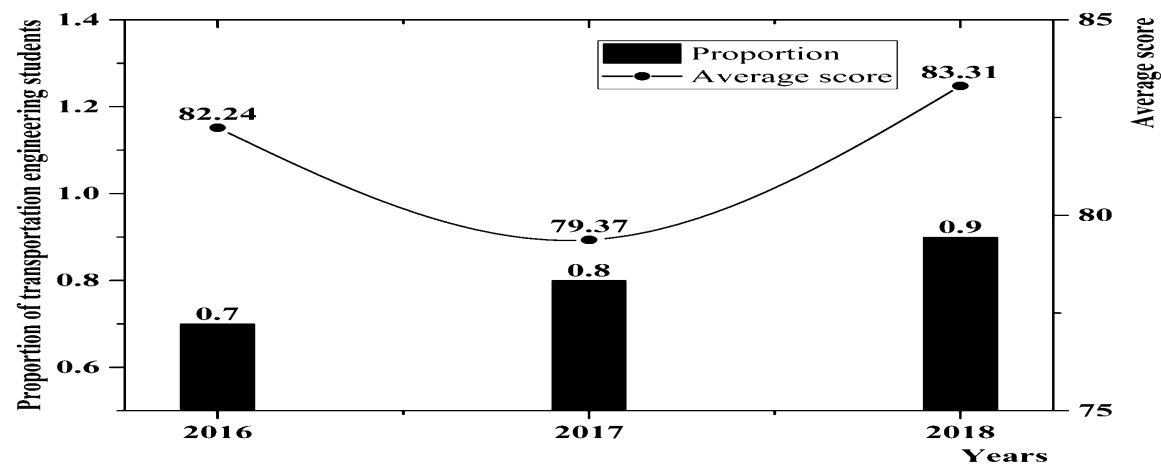

Figure 2. Proportion of transportation engineering students and average scores

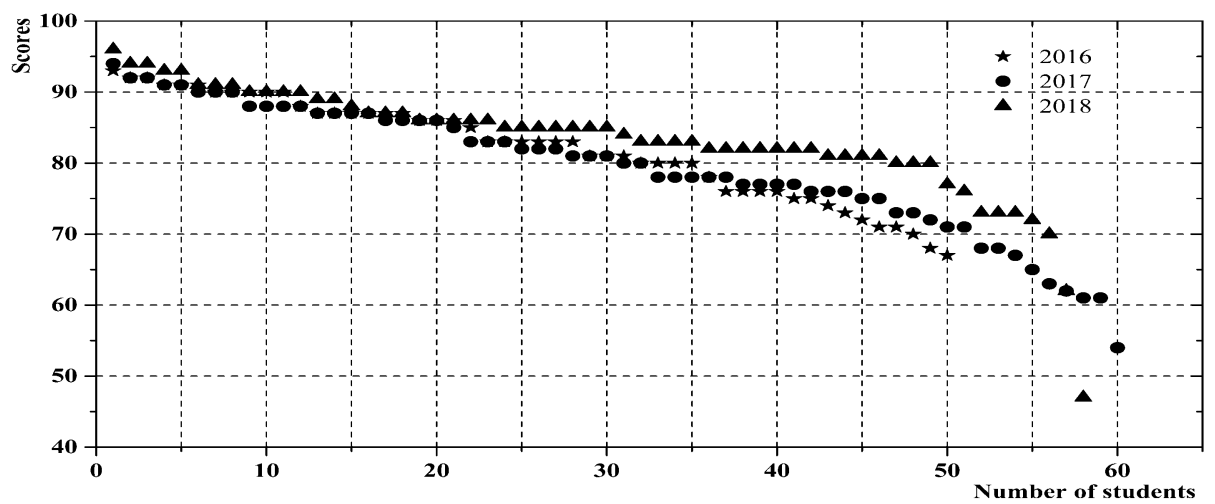

Figure 3. Scatter plot of achievement score

The students who choose this course are mainly in traffic engineering, except for a few other professional students. It can be seen from Figure 2 that the proportion of transportation majors choosing this course has increased year by year. This indicated that the course is more popular among students and is becoming more and more important in transportation education. However, it can be seen from Figure 2, although content and teacher of the course is the same in the past three years, there is a significant fluctuation in the average score distribution of the students. In order to further analyze the reasons for the fluctuation in student performance, we listed the scores of students who choose the course from high to low in the past three years, as shown in Figure 3. It can be seen that the high segmentation is basically flat, while the low segmentation is getting higher and higher in the past three years. This shows that the curriculum is continuing to improve. In addition, there is a contradiction of fluctuation trend between the average score individual scores. Therefore, it is necessary to further analyze the achievement of students and judge whether they have met the requirements for graduation. 
Shen, Liu, Ma, Qi, Zheng / Outcomes-Based Evaluation of Graduation Requirements for Traffic Engineering...

\section{Analysis results of the exam scores analytical method}

According to the graduation requirements indicators of traffic engineering education, we decompose the scores of the students who choose the road traffic safety curriculum over 3 years. The evaluation indicators are list in Table 1. Taking the indicator 2-4 for example, based on the Equation 1, if the average score of the indicator point 2-4 is 18 points and the score of all the items is 20 points, then the evaluation value of the indicator 2-4 is $18 / 20=0.900$. Then the contribution value of the course to indicator $2-4$ is obtained considering the weight of the course to indicator 2-4. According to the evaluation records, the scores of each student were analyzed, and the evaluation results of the calculated achievement indicator were calculated, as shown in Table 3.

Table 3

Evaluation Value of the Graduation Requirements

\begin{tabular}{|c|c|c|c|c|c|}
\hline \multirow{2}{*}{ Category } & \multirow{2}{*}{$\begin{array}{l}\text { Target } \\
\text { value }\end{array}$} & \multicolumn{3}{|c|}{ Evaluation value } & \multirow{2}{*}{ Teaching objectives } \\
\hline & & 2016 & 2017 & 2018 & \\
\hline \multicolumn{6}{|c|}{ Graduation requirements1: Engineering knowledge } \\
\hline $1-4$. & 0.2 & 0.165 & 0.163 & 0.164 & $\begin{array}{l}\text { Learn the professional knowledge of road traffic safety } \\
\text { and be able to apply the knowledge learned to solve } \\
\text { relevant engineering problems. }\end{array}$ \\
\hline \multicolumn{6}{|c|}{ Graduation requirements2: Problem analysis } \\
\hline $2-2$ & 0.2 & 0.157 & 0.161 & 0.162 & $\begin{array}{l}\text { Understand the basic principles of mathematics and } \\
\text { natural science knowledge, and transform, express and } \\
\text { analyze the complex characteristics of transportation } \\
\text { systems. }\end{array}$ \\
\hline \multicolumn{6}{|c|}{ Graduation requirements4: Problem analysis } \\
\hline $4-2$ & 0.2 & 0.156 & 0.159 & 0.160 & $\begin{array}{l}\text { Learn to analyze and interpret the data of complex } \\
\text { traffic safety problems and obtain effective } \\
\text { conclusions. }\end{array}$ \\
\hline \multicolumn{6}{|c|}{ Graduation requirements5: Problem research } \\
\hline $5-2$ & 0.2 & 0.142 & 0.140 & 0.145 & $\begin{array}{l}\text { Master relevant computer software and simulation } \\
\text { tools, apply the knowledge learned to analyze and } \\
\text { synthesize data on relevant issues, and obtain effective } \\
\text { conclusions. }\end{array}$ \\
\hline \multicolumn{6}{|c|}{ Graduation requirements10: Communication } \\
\hline $10-1$ & 0.2 & 0.149 & 0.146 & 0.148 & $\begin{array}{l}\text { Ability to write high quality analysis reports and } \\
\text { effective design plans for complex traffic safety } \\
\text { problems. }\end{array}$ \\
\hline
\end{tabular}

It can be seen from Table 4 that the evaluation value of each indicator exceeds $70 \%$ of the target value, indicating that the evaluation is qualified. It can be found that students have relatively strong mastery of basic theoretical knowledge, since indicator 1-4 has the highest score. The lowest score of indicator is 5-2, which means the students are relatively weak in the practical application of knowledge. In addition, the students' enthusiasm for the course experiment was very high. The subsequent hours of the course experiment could be appropriately increased.

\section{Analysis results of rubrics method}

The SCTE conducted a questionnaire survey on students who had taken road traffic safety courses in 20162018. 169 questionnaires were distributed and 165 were returned, of which 162 were valid. Based on these questionnaires, the Rubrics evaluation value of each student are calculated, as is shown in Figure 5. 


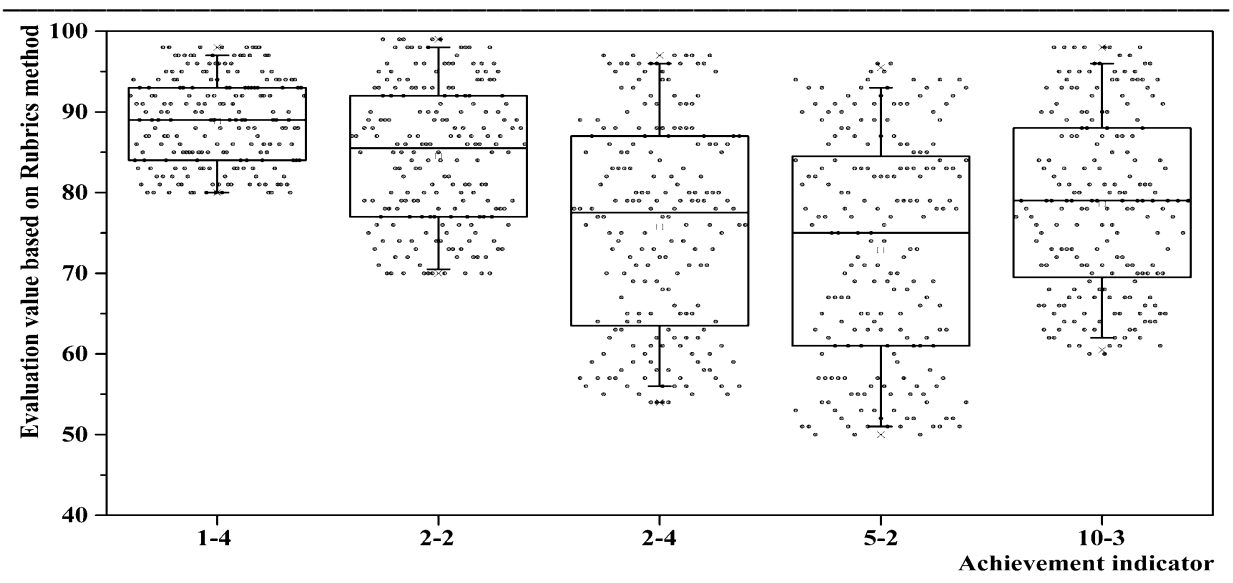

Figure 5. Rubrics evaluation value of each student

Subsequently, according to the sample table, the members of the SCTE gave an evaluation opinion on the course. Finally, the lecturer gave feedback based on the evaluation opinions given by the teaching guidance committee and wrote the corrective measures. The average Rubrics evaluation value, SCTE evaluation opinions and the feedback of key teachers are shown in Table 5.

Table 5

Average Rubrics evaluation value, SCTE evaluation opinions and the feedback

\begin{tabular}{lc}
\hline Course & Road traffic safety \\
\hline Category of personnel & SCTE and the lecturer \\
Evaluation time & April 2018
\end{tabular}

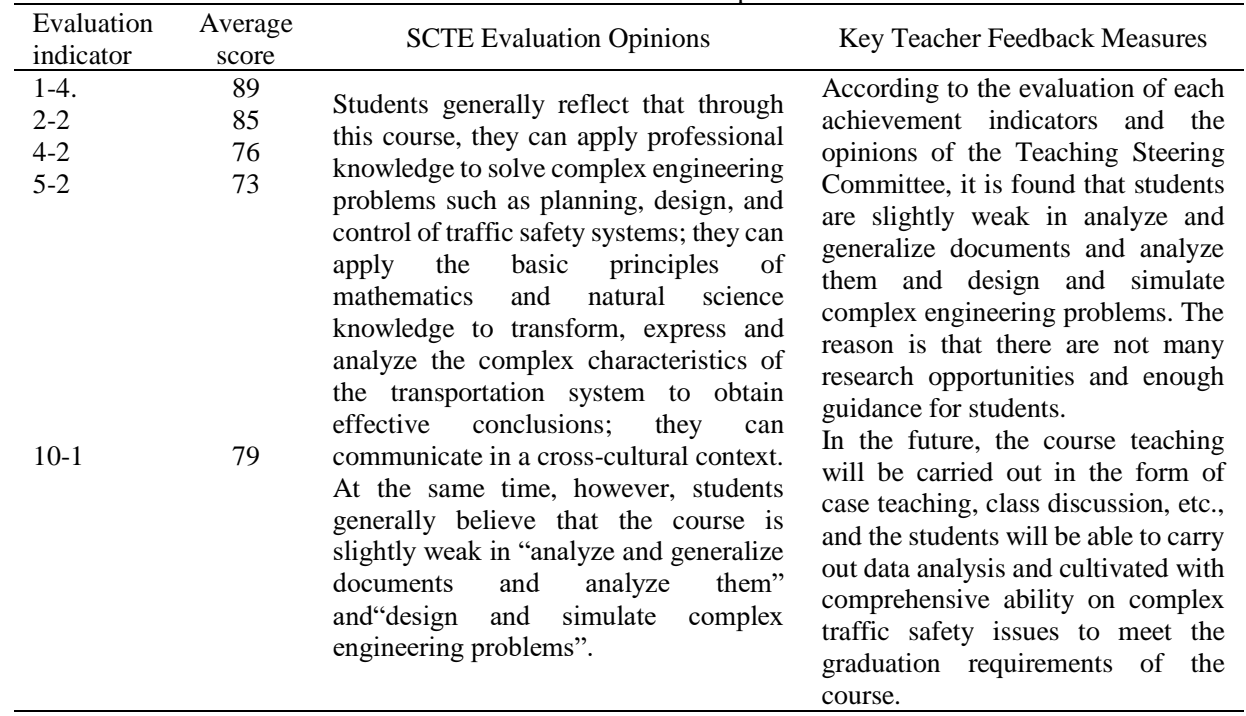

As can be seen from Figure 5, the indicators 1-4, 2-2 have an average score of 80 or more, and the degree of dispersion is small. Indicators 4-2 and 5-2 are below 80, and the degree of dispersion is large, indicating that students have a greater degree of mastery of relevant knowledge and skills. At the same time, the Teaching Steering Committee also gave an evaluation opinion on the course. The lecturer proposed continuous 
Shen, Liu, Ma, Qi, Zheng / Outcomes-Based Evaluation of Graduation Requirements for Traffic Engineering...

improvement measures based on the evaluation opinions of the Teaching Steering Committee.

In the process of course evaluation, the staff faces difficulties in evaluating data with high work intensity. It is necessary to develop an evaluation system platform to design the various aspects of the curriculum and teaching activities. Realize the real-time input of various data of the evaluation students, and automatically form data results and analysis tables.

\section{Conclusion}

The engineering education accreditation system is an internationally accepted quality assurance system for engineering education. It is also an important basis for achieving international mutual recognition of engineering education and engineer qualifications. From the perspective of professional talent training, the evaluation of graduation requirements is the core link in the teaching quality assurance and feedback mechanism.

In China, the accreditation of engineering education emphasizes the following three basic concepts. First, it emphasizes on student-orientation and students are the primary target of service. The satisfaction of students and employers with the services provided by the school or major is an important indicator of whether they can pass the accreditation. Second, it emphasizes student-centeredness and student-led output. Evaluate the effectiveness of professional education by comparing the core competence and quality requirements of graduates. Third, it emphasizes qualified evaluation and continuous improvement of quality. Professional accreditation emphasizes the basic quality requirements of engineering education. It also requires the professional to establish a continuous and effective quality improvement mechanism.

How to effectively evaluate the achievement of graduation requirements is the key to implementing the $\mathrm{OBE}$ theory. The purpose of professional engineering education accreditation is to promote professional development of output-oriented internal evaluation and improvement mechanisms. It is the connotation of improving the quality of undergraduate talents training by adopting the diversity evaluation method that suits the professional characteristics and different graduation requirements. In the process of designing and using the two methods of exam scores analytical method and rubrics method.

According to the main issues of graduation requirements in the engineering education accreditation system, outcomes-based evaluation with the exam scores analytical method and rubrics method is analyzed in this paper. Taking road traffic safety curriculum as an example, based on the analysis of the relationship between graduation requirements and curriculum contents, graduation requirement evaluation indicator and weight coefficient of the curriculum contents are determined. Then, test scores of 169 students, who have taken road traffic safety curriculum in the past three years, were selected to calculate the achievement of each evaluation indicator point based on exam scores analytical method. It can be found that relatively students have a strong mastery of basic theoretical knowledge but a weak practical application of knowledge. In addition, the enthusiasm of students for the course experiment was very high. The subsequent hours of the course experiment could be appropriately increased. Moreover, on the basis of 162 valid questionnaires, the quantitative evaluation data of the graduation requirements for the curriculum contents are calculated. And the rubrics evaluation value, evaluation opinions and the feedback of key teachers are obtained by the rubric's method. The evaluation results 
Shen, Liu, Ma, Qi, Zheng / Outcomes-Based Evaluation of Graduation Requirements for Traffic Engineering...

$\overline{\text { indicate that students have a greater degree of mastery of relevant knowledge and skills. In the process of course }}$ evaluation, the staff faces difficulties in evaluating data with high work intensity. It is necessary to develop an evaluation system platform to design the various aspects of the curriculum and teaching activities. Realize the real-time input of various data of the evaluation students, and automatically form data results and analysis tables.

The research in this paper can provide guidance to better improve the quality of course construction and meet the graduation requirements of engineering education accreditation. However, it should be noted that these methods should not be used alone but should be comprehensively used according to professional conditions and characteristics. The research in this paper can provide references in improving of the quality of transportation personnel training and the engineering education accreditation of other related majors.

\section{References}

Anwar, A. A., \& Richards, D. J. (2018). A comparison of EC and ABET accreditation criteria. Journal of Professional Issues in Engineering Education \& Practice, 114(3), 6018001-5.

Anwar, A. A., \& Richards, D. J. (2013). Is the USA set to dominate accreditation of engineering education and professional qualifications?. Proceedings of the Institution of Civil Engineers-Civil Engineering, 166(1), 4248.

Barman, L., Silen, C., \& Laksov, K. B. (2014). Outcome based education enacted: Teachers' tensions in balancing between student learning and bureaucracy. Advances in Health Sciences Education, 19(5), 629643. http://dx.doi.org/10.1007/s10459-013-9491-3

Chaubey, A., Bhattacharya, B., \& Das Mandal, S. K. (2018). Attributes of good teaching in engineering education in Indian subcontinent. Sadhana-Academy Proceedings in Engineering Sciences, 43, 188-200.

Deneen, C., Brown, G. T. L., Bond, T. G., \& Shroff, R. (2013). Understanding outcome-based education changes in teacher education: Evaluation of a new instrument with preliminary findings. Asia-Pacific Journal of Teacher Education, 41(4), 441-456. http://dx.doi.org/10.1080/1359866X.2013.787392

Hodgson, R. M., \& Williams, B. R. (2007). Engineering education, accreditation and the Bologna declaration: A New Zealand view. International Journal of Electrical Engineering Education, 44(2), 124-128. http://dx.doi.org/10.7227/IJEEE.44.2.6

Kim, H. S. (2012). Outcomes-based curriculum development and student evaluation in nursing education. Journal of Korean Academy of Nursing, 42(7), 917-927. http://dx.doi.org/10.4040/jkan.2012.42.7.917

Li, S. (2018). Innovations in Chinese engineering education with digital technologies: A brief review of recent advances. Computer Applications in Engineering Education, 26(5SI), 1081-1088.

Mukhopadhyay, S., \& Smith, S. (2010). Outcome-based education: Principles and practice. Journal of Obstetrics and Gynaecology, 30(8), 790-794. http://dx.doi.org/10.3109/01443615.2010.505305

Mutereko, S. (2018). Analysing the accreditation of engineering education in South Africa through Foucault's panopticon and governmentality lenses. Assessment \& Evaluation in Higher Education, 43(2), 235-247. http://dx.doi.org/10.1080/02602938.2017.1330395 
Shen, Liu, Ma, Qi, Zheng / Outcomes-Based Evaluation of Graduation Requirements for Traffic Engineering...

Schiekirka, S., Anders, S., \& Raupach, T. (2014). Assessment of two different types of bias affecting the results of outcome-based evaluation in undergraduate medical education. BMC Medical Education, 14,149-158. http://dx.doi.org/10.1186/1472-6920-14-149

Staniskis, J. K., \& Katiliute, E. (2016). Complex evaluation of sustainability in engineering education: Case \& analysis. Journal of Cleaner Production, 120, 13-20. http://dx.doi.org/10.1016/j.jclepro.2015.09.086

Svanstrom, M., Sjoblom, J., Segalas, J., \& Froling, M. (2018). Improving engineering education for sustainable development using concept maps and multivariate data analysis. Journal of Cleaner Production, 198, 530540 .

Tan, K., Chan, C. M., Subramaniam, P., \& Ping, W. L. (2018). The effectiveness of outcome-based education on the competencies of nursing students: A systematic review. Nurse Education Today, 64, 180-189. http://dx.doi.org/10.1016/j.nedt.2017.12.030

Thurer, M., Tomasevic, I., Stevenson, M., Qu, T., \& Huisingh, D. (2018). A systematic review of the literature on integrating sustainability into engineering curricula. Journal of Cleaner Production, 181, 608-617. http://dx.doi.org/10.1016/j.jclepro.2017.12.130

Wikle, T. A. (2018). A rationale for accrediting GIScience programs. Cartography and Geographic Information Science, 45(4), 354-361. http://dx.doi.org/10.1080/15230406.2017.1375431 